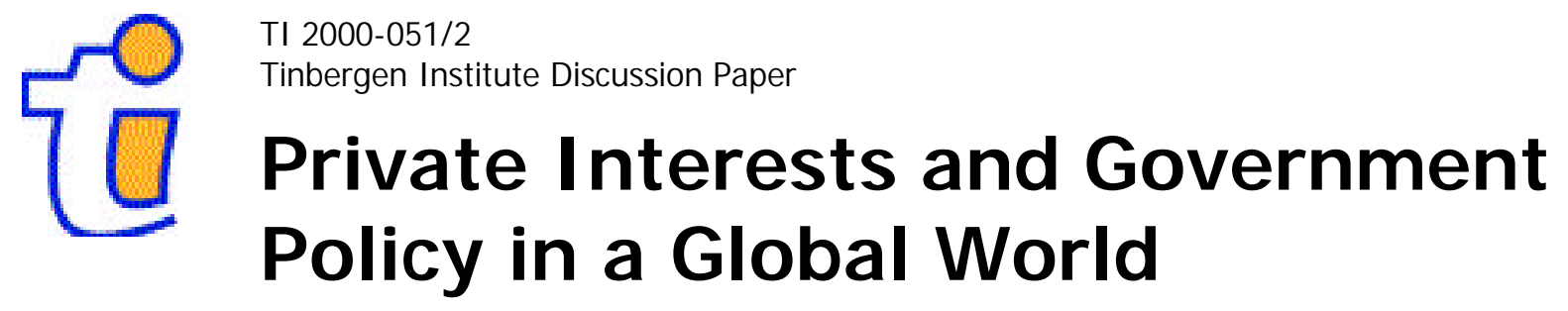

Ronald W. Jones 
Tinbergen Institute

The Tinbergen Institute is the institute for economic research of the Erasmus Universiteit Rotterdam, Universiteit van Amsterdam and

Vrije Universiteit Amsterdam.

Tinbergen I nstitute Amsterdam

Keizersgracht 482

1017 EG Amsterdam

The Netherlands

Tel.: +31.(0)20.5513500

Fax: $\quad+31 .(0) 20.5513555$

Tinbergen I nstitute Rotterdam

Burg. Oudlaan 50

3062 PA Rotterdam

The Netherlands

Tel.: $\quad+31 .(0) 10.4088900$

Fax: $\quad+31 .(0) 10.4089031$

Most TI discussion papers can be downloaded at

http://www.tinbergen.nl 


\title{
Private Interests and Government Policy in a
}

\section{Global World}

\author{
Ronald W. Jones* \\ University of Rochester \\ Rochester, NY 14627
}

As the new century begins, much attention is being paid to the extent to which

globalization characterizes international economic relations. ${ }^{1}$ It is not just that the volume of international trade, even relative to national incomes, is growing. The nature of such trade is also changing, with intermediate goods and goods in process becoming more important components. Vertical production processes are being fragmented, with separate pieces of this process being outsourced to countries that have particular advantages in providing the inputs in which such fragments are intensive in their use, whether it be unskilled labor, skills, capital, or cheap energy sources. The costs involved in such fragmentation have been reduced dramatically, including not only transportation costs but also the costs of conveying information, the costs of monitoring deliveries and co-ordination, and the costs involved in dealing in arms-length transactions with foreigners. $^{2}$

These changes in the manner and form in which private world commerce is conducted have important implications for national government policies. In this paper I shall sketch some of the implications of this increased importance of international exchange of inputs to the production process. I begin with a discussion of the central role played by the concept of absolute advantage once international trade in inputs is explicitly allowed. This sets the stage for considering the two standard roles for government that receive 
special attention in typical treatments of international trade policy. Finally, I turn to an alternative possible scenario that highlights potential conflicts between private interests and government interests in a world that is increasingly becoming globalized.

\section{A Reconsideration of Comparative and Absolute Advantage}

The concept of comparative advantage has been considered the corner-stone of the pure theory of international trade since the time of Ricardo. It suggests that regardless of the absolute level of productivity in a country, an export position can be established for those commodities in which the country's comparative productivity is highest, even if this means that the country exports these items to other nations in which the absolute level of input productivity is even higher. The basis for this proposition is that such inputs are trapped behind national barriers. A lower absolute level of productivity is reflected in lower returns to these factors compared with returns received in other countries. Such a discrepancy in returns can be maintained in equilibrium if the inputs are not internationally mobile.

Government regulations, levels of taxation, and provision of what is sometimes called social overhead capital can likewise affect the productivity or net returns of inputs. To the extent that such benefits or costs are spread relatively uniformly over various sectors of the economy, they will not affect the pattern of international trade if no inputs have international markets. In such an event a comparison of the nature of governmental control from country to country may be important in comparing the welfare of productive factors in these countries, but would not be relevant in considering the pattern of trade. If, instead, some inputs can be exchanged in world markets, the concept of absolute 
advantage comes into its own in affecting the composition of national outputs and the direction of international trade. .

To see what is entailed, consider a simple (augmented) Ricardian case in which the home country can produce two commodities, $X$ and $Y$, each utilizing that country's labor force, which is internationally immobile. ${ }^{3}$ Whereas commodity $X$ uses only labor, suppose that to produce commodity $Y$ a fixed amount of some other input, say capital, is required to produce each unit of output. This capital is assumed to be internationally mobile, implying that its net return, $R$, will be driven to equality in every country in which production of $Y$ takes place. Assuming rigid technology (fixed input-output coefficients), the world prices, $\mathrm{p}_{\mathrm{j}}$, at which both commodities could be produced at home would be shown by equations (1) and (2), where $w$ denotes the wage rate, and $R$ the return to capital:

(1) $\quad \mathrm{a}_{\mathrm{LX}} \mathrm{W}=\mathrm{p}_{\mathrm{X}}$

$$
a_{L Y} W+a_{K Y} R=p_{Y}
$$

Now divide equation (1) into equation (2) to obtain the relationship shown in Figure 1. If the world price ratio, $\left(\mathrm{p}_{\mathrm{Y}} / \mathrm{p}_{\mathrm{X}}\right.$ ), and world rate of return to mobile capital (in $X$-units), $R / \mathrm{p}_{\mathrm{X}}$, should happen to fall on the upward sloping line, the home country could produce both commodities. If the world price point lies below this line, the home country could not compete in producing commodity $Y$, since the relative costs of doing so when $R$ must be paid for the hire of a unit of capital would exceed the relative price of $Y$. By contrast, if 
the world price and return combination is indicated by a point above the line, the home country could not compete in $X$-production; the wage rate that could be earned by specializing in the production of commodity $Y$ would result in losses to any potential producer in the X-sector. Note that the vertical intercept of the line indicates the relative labor costs, $a_{L Y} / a_{L X}$, while the slope of the line, $a_{K Y}$, is the inverse of the productivity of capital.

Compare this situation in the home country with that in some foreign country (indicated by an asterisk, *). Figure 2 provides this comparison, where labor and capital productivities are assumed to differ. The home country is shown as having a comparative advantage in labor costs in producing $Y$, whereas the foreign country is assumed to be more efficient in its utilization of capital. If the cost of hiring capital is low on world markets, the home country would have a relatively lower cost of producing commodity $Y$. Even if home labor became only half as productive in making these two commodities, the same result would hold; trade patterns are not affected by the absolute level of productivity of the nationally-trapped input. But a similar remark cannot be made for the relevance of absolute productivities of internationally-mobile capital. Thus suppose the home country becomes half as productive as previously in both labor (uniformly over sectors) and capital. The slope of the $\boldsymbol{H}$ line in Figure 2 would double. If world commodity prices and return on capital are indicated by point $E$, such a halving of input productivities at home would cause the home country to change its production pattern from being completely specialized in producing $Y$ to putting all its labor into producing commodity $X$, thus joining the foreign country, which remains specialized in $X$. 
Labor and capital productivities can be affected by government actions, e.g. in the supply of road networks, harbors, and other social-overhead capital. If this affects all the input-output coefficients uniformly, it would not affect trading patterns in a world exhibiting the classical paradigm whereby only final commodities enter into world commerce. However, once some input (such as capital in Figure 2) becomes internationally mobile, its location (and hence the pattern of production and trade) does become sensitive to government policies.

How about taxation? If capital is internationally mobile, it wants to go where its return, net of taxes, is maximized. Thus suppose the home country imposes a uniform levy, $t$, on any incomes earned at home, whether in the form of wages or return to capital. Denoting the world rate of return on capital by $R$, producers of $Y$ at home would have to pay the gross amount, $\mathrm{R} /(1-\mathrm{t})$, to attract capital from the world market. With reference to equation (2), this is akin to an increase in the input output coefficient for capital to $\mathrm{a}_{\mathrm{KY}} /(1-\mathrm{t})$. The $\boldsymbol{H}$-line in Figure 2 would once again become steeper (although the vertical intercept remains the same - labor's take-home pay would be reduced). Such taxation would serve completely to drive out the $Y$-industry at home if world prices are given by point $E$. A nation's immobile factors cannot escape uniform taxation at home, but mobile factors can. Immobile factors ask, "what should we do", whereas mobile factors ask "where should we go". The answer to the latter question depends sensitively on a comparison among countries of government attitudes towards business, taxation, and the provision of services. Such a comparison is less relevant in the classical world in which inputs are contained by national borders. 


\section{Government Policies for National Welfare}

Having established that with the international mobility of some productive input(s), an asymmetry of government policies among countries can have an effect on the pattern of trade, I turn to the most basic argument for commercial policy found in traditional theory, viz. the "terms-of-trade" argument. If a country is big enough that its actions affect world prices, an import duty or an export tax can be utilized to lower the relative world price of its imports. The usual caveats apply, especially that other countries do not retaliate with barriers to trade of their own or that, if they do, the result of such a tariff war still leaves the home country a winner compared with free trade. With international mobility of some input(s), what is added is the effect of commercial policies on the world returns to such factors. These effects complicate the terms-of-trade argument because a move to improve the relative price of the nation's exports in world markets might also serve to lower the return to an input that is utilized abroad but owned by home residents. I return to this possibility below.

Although a small open economy cannot improve its national welfare by levying tariffs if markets are competitive, it can lower its welfare if it raises the tariff rate from a preexisting positive level. ${ }^{4}$ In general a country's welfare is raised if the world price of its export commodity rises or the world return on an exported import improves (or return on an imported input falls). These are the terms-of-trade effects, and for a small open economy these are absent. Additionally, there are the volume-of-trade effects: An increase in the volume of imports would raise real income if the price at which these imports can be obtained is lower than the valuation placed on them by consumers or producers; this price spread is precisely what a pre-existing import tariff brings about. 
There is also a volume-of-trade effect possible if the home country taxes trade in the input, but I assume no such interference exists for this small open economy. The consequence is that an increase in the tariff rate from a positive base has the effect on real income illustrated in equation (3), where real income or welfare (measured in units of the export commodity) is denoted by $y$, the volume of imports by $M$, the ad-valorem tariff rate by $t$, and the world price of imports (assumed fixed) is shown by $p^{*}$ (and thus the tariff wedge by $\left.t p^{*}\right)$ :

$$
\mathrm{dy} / \mathrm{dt}=\mathrm{tp}^{*} \mathrm{dM} / \mathrm{dt}
$$

The key to the result that a small country with a pre-existing tariff on imports hurts itself by raising that tariff rate is that the term on the right-hand side of equation (3) is negative. This is so for two reasons. First is the standard substitution effect in consumption and production whereby an increase in the domestic price of imports causes demand to fall and local production to rise. Second is the additional effect brought about by an induced change in the international location of the mobile input. To keep matters simple, I assume that this input (say physical capital) is specifically used either to produce the importable or to produce the exportable. If it is used in the importable, its local return will rise when the domestic price of importables is increased by the tariff hike. This serves as a signal for more of the input to flow from abroad, where its return is fixed (by the small country assumption). The consequence of this inflow is that local production of importables goes up, thus reducing the volume of imports. Alternatively, if the internationally mobile input is a specific factor in the nation's export sector, the tariff 
increase lowers the relative domestic price of exportables and, with it, the return to the mobile input. This causes an outflow of this input back to the world market, serving to reduce the local production of exportables (and shifting resources to the importcompeting sector). Once again the volume of commodity imports falls. Figure 3 illustrates that an increase in the tariff rate on commodity imports causes real incomes at home to fall, and that this fall is even more pronounced if an input (here capital) is internationally mobile. Thus the negative consequences on a country's real income of a small open economy exercising commercial policy become more severe if factor inputs as well as commodity outputs are traded on world markets. Raising the tariff rate sends out a false signal for international capital flows, and the location of capital readjusts in a fashion that serves further to cut back on imports ${ }^{5}$.

This strong theoretical result is rendered somewhat mute because of the existence in the real world of tax arrangements among countries whereby host nations get first crack at taxing the income streams earned by foreign investors. The possibility that a small open economy might gain by attracting foreign investment, even net of any subsidy arrangements that serve to induce entry by the foreign investor, is most clearly evident if the purpose of the investment is not to supply the local protected market, but to establish a production base for exports. In this event local production (and therefore the income flow) is not constrained by local demand. Shifting the locale of production of goods destined for the world market can well be in a country's interest if it can obtain tax revenues in this fashion.

Return, now, to the large-country case. The terms-of-trade argument previously sketched out was developed for competitive markets. The emphasis in "new trade 
theory" has been on the existence of imperfect competition and, in some cases, increasing returns to scale. The theoretical result which probably has had most influence in the policy area is that of Brander and Spencer (1985), which provides an analytical rationale for a country to subsidize its export activity. (The possible use of subsidies is not alien to the competitive case, e.g. to lower the foreign price of a country's exports when the home country has an even greater value of exports of an intermediate good used to produce foreign exports). The Brander/Spencer scenario has a large exporting firm in one country competing in a final goods market abroad with a large foreign producer. In their Cournot duopoly setting the authors argue that the home government can, through its export subsidy, provide a credible means of encouraging the foreign firm to cut back on its exports and the home country can gain by getting a bigger slice of profits earned in this world market. On theoretical grounds the conclusion is quite sensitive to the assumptions, for example the use of the Cournot setting instead of competition in prices (Eaton and Grossman, 1986). As well, with other export activities explicitly considered, a "Dutch Disease" result may easily occur, whereby helping one export sector with subsidies ends up hurting other export sectors since wages or other returns used in that sector get bid up (Dixit and Grossman, 1986).

The existence of trade in raw materials or intermediate goods as well as in final goods serves to highlight the way in which national policy can be altered in this imperfectly competitive setting. For example, Spencer and Jones (1991) consider the case in which a country has a strong advantage in the export of a raw material or intermediate which is used both at home and abroad as an input into a final commodity sold on world markets. Suppose this final good is characterized by duopolistic competition, as in the 
Brander/Spencer scenario. Then subsidizing exports of the final good, which causes foreign production to fall, may not be welfare-improving if a larger return is made on the exports of the intermediate to foreign rivals.

\section{Government Policy to Aid Special Interests}

It may seem naï ve to assume that government bases its policies on the criterion of the national welfare, although it remains useful as a benchmark to consider the aggregate welfare effects of policies. Instead, much attention has been focussed on the use of trade policy to aid particular interest groups, perhaps those best placed to affect the outcome of elections or provide financial support to political parties. The accumulating literature in this area is vast, and well developed and documented in Arye Hillman (1989) and Dani Rodrik (1995).

One of the real-world examples I find useful in the classroom concerns the United States and Canada in a softwood lumber dispute in 1987. Canada has more ample supplies of softwood lumber (especially relative to home demand) than does the United States. Some would argue this is "unfair", and at this time the United States threatened Canada with a $15 \%$ import duty. At the last moment the United States offered to drop its planned tariff hike if the Canadians, in exchange, would proceed in a manner which, if done in the United States, would be unlawful, indeed un-Constitutional, viz. levy an export tax of $15 \%$. The effect of this alteration on private lumber interests in the United States was trivial, but it meant that the potential "import tax revenue" was handed over to Canada. The interests of private groups clearly outranked any concern with aggregate welfare. 
The income distribution consequences of commercial policy have long been of central importance in international trade theory. The Stolper-Samuelson theorem, over fifty years in age, was originally considered shocking because it suggested that even if a country's tariff served to lower national welfare, it could unambiguously improve the lot of aggregate labor in real terms (and this without dipping into the tariff revenue).

Although often criticized for its small-dimensional basis, the Stolper-Samuelson theorem does indeed generalize in the following form: Could government unambiguously come to the aid of any pre-selected factor of production, not by a direct subsidy, but indirectly by using expenditure or taxation policy to alter relative prices of commodities? In theory the answer is yes, if two fairly weak conditions are satisfied: There is no joint production and there is a sufficiently large number of independent commodity markets (at least as many as the number of productive factors). ${ }^{6}$ Since the appearance of the original StolperSamuelson article, interest in the effects of public policies on the distribution of income has only heightened. The specific-factors model of production is perhaps even better suited to pursuing the effects of policy on special interests than the Heckscher-Ohlin model (underlying the Stolper-Samuelson result). A tariff on any import-competing sector of the economy serves to drive up the real return to the factor that is used specifically in that sector and can prevent entry of similar factors from other sectors. Specific factors are all about rents, and government policies and regulations have the effect of re-distributing such rents as well as controlling entry into specific occupations.

The specific-factors model is also useful in emphasizing the close relationship between the fate of a particular industry (as affected, say, by the tariff structure) and the 
return to the factor used specifically in that industry. Call this a kind of "capital". As was made clear in the earlier literature on effective protection (e.g. Corden, 1966), the nominal tariff rate on an import yields only an imperfect guide to the extent of protection granted to local inputs when production requires as well the use of imported intermediates. If tariff rates on intermediates are lower than that levied on the final good, the effective rate of protection to local factors is even greater than the nominal rate on the final good. Now take this one step further to consider the consequences of the tariff structure on the returns to specific factors used in each industry. Compare two industries being considered for protection at the same effective rate. Each uses labor drawn from a common pool as well as sector-specific capital. If they face the same effective rate of protection, in which sector would the return to specific capital rise more? The answer: In the labor-intensive sector - the sector with the higher distributive share going to labor. In each sector the (same) effective rate is a weighted average of the change in the wage rate (less than the effective rate) and the changed return to sector-specific capital (greater than the effective rate). Therefore the lower the share of specific capital, the more its return must rise. And note the possibilities of plausible-sounding spin for this industry: "Protect us because we are very labor-intensive."

Increased international trade in inputs, international mobility of factors, and the increased "fragmentation" of vertical production processes so that the entire activity need not be produced in one place, all change the nature of government policy that is aimed to protect special interests. Some factors are internationally mobile and others are not. For the mobile factors, national policies that are harmful can perhaps be avoided by moving to a different national jurisdiction. Such movement would in general 
have a deleterious effect on those left behind. This leads to an important implication of globalization for national government policy: Globalization of the type envisaged here serves both to increase the demand for government intervention (to protect the welfare of non-mobile factors) and to lower the supply of the means at the government's disposal to effect such protection.

The international mobility of financial capital implies that real incomes of individuals need not share the same fate as a country's terms of trade. Diversification of assets is especially attractive in a world of uncertainty (e.g. as discussed in JoAnne Feeney and A. Hillman, 2000). If a country's commercial policy is aimed at maximizing the national welfare, the proper "terms of trade" to be taken into account is not the same as a mere ratio of prices of final goods imports and exports. Just as trade in intermediate goods and foreign investment of capital alter the welfare significance of price changes, so also account must be taken of the composition of private individual asset holdings. However, the distinction between those who can take advantage of international mobility from those (e.g. unskilled laborers) who cannot still carries weight in public policy decisions. For example the loss of a production facility in the United States to a locale in Mexico would not be viewed with indifference by the workers involved, even if they were invited to purchase foreign securities.

\section{The "Civil War" Scenario}

There is no doubt that certain government policies strongly favor particular interests in the private sector of the economy, and that certain elements of the private sector come to depend heavily on government policy biased in their favor. Without denying this link, 
let me construct here a different scenario that may well illustrate some of the relationships between government and private sectors in many economies, both developed and less developed. It is a scenario in which there is a constant "civil war" being waged between public and private sectors. It is based on the following extremely simple assumptions: Suppose that the motivation of government is to control, monitor, regulate and tax activities in the private sector. Aside from trying to influence government policy in their favor, the motivation of many in the private sector is to attempt to avoid such regulation. The forces of globalization have offered the private sector more opportunities to avoid public sector regulation, and these same forces have encouraged national governments to seek alliances with other national governments. Even if such alliances serve to compromise the sovereign powers of national governments, the pay-off is measured in terms of extending the domain of control and regulation a government has over its own citizens who chose to operate abroad.

A common theme running through the literature on political economy is that the motivation of politicians lies in their desire to get re-elected. This view helps in understanding which special interest groups get favorable treatment. But more is involved, and this concerns not only politicians but also the bureaucracy. ${ }^{7}$ How can one expand the demand for governmental services? One way is by increasing the scope and complexity of regulations. And an important input into this process is to convince the public at large that it needs public assistance in certain areas. For example, in the United States the Full Employment Act in the late 1940's greatly expanded the accepted role of government in assuming responsibility for high levels of employment. 
The question of the distribution of income is now considered to lie within the purview of government. In the United States there has been a concern over the relative deterioration of unskilled wage rates. There appears to be no real consensus among economists whether the blame should reside with international trade and the increased importance of low-wage countries in world markets, or with the supposed lack of technical progress in the past couple of decades and the labor-saving bias of progress that has taken place, or with the failure of the educational establishment to train the younger generation in the skills required with modern technology. Regardless of the cause, the government is concerned with all these possibilities, and considers trade restrictions, industrial policies to support high-technology sectors, and new expenditures in the educational areas as potential legitimate public activities. Recent additions to the portfolio of government concerns include social insurance (flood relief and help with other natural disasters), environmental matters, and health.

What can private sector interests do if faced with increasing national regulation (and taxation)? Fleeing the jurisdiction is one option. This is where the consequences of increased globalization come to play. The costs of fleeing one national jurisdiction for another have been decreasing. Laura Tyson, in her 1992 book, Who's Bashing Whom: Trade Conflict in High Technology Industries, discusses the world semi-conductor industry in the 1980's. Early in the decade Japanese producers were taking the lead in developing new generations of DRAM computer chips. In an effort to protect the U.S. industry, anti-dumping suits against the Japanese were considered and, in response, Japanese semi-conductor firms were encouraged to co-operate among themselves and raise prices. This resulted in what Tyson calls a $\$ 4$ billion "bubble", transferring income 
from (U.S) users of chips to Japanese producers, and U.S. firms were threatening to move off-shore in order to reduce input prices. This episode serves to highlight the variation in the "Dutch Disease" introduced when international trade takes place in inputs as well as outputs: Supporting one input industry easily raises costs to the national user industry. If private industrial sectors were trapped by national boundaries, the issue would primarily be one of favoring one sector at the expense of collecting rents from another. However, if the national borders are porous, the adversely affected private firms could seek alternative jurisdictions abroad that offer less costly sets of taxes and regulations.

What recourse does the public sector have when faced with the possibility that private firms or individuals may take advantage of other jurisdictions with more favorable treatment,? One possibility is to come to arrangements with other public sectors (governments) in an attempt both to share information about the private activities of one set of citizens in other countries and perhaps to re-align public policies and regulations so as to offer fewer opportunities to the private sector to "shop around" to get better terms in other countries. The word harmonization is often used to describe the process whereby taxation rates and regulations of one country are brought into line with that of others. Could another word for harmonization be collusion? Even if such co-operation among governments may involve an element of loss of sovereignty, public sectors may be willing to make that sacrifice if, in return, the agreements enlarge the umbrella of regulation and control that public sectors can use in their dealings with their own national private sectors. Public sectors may turn away from their classic role of alliance with their own private sectors in opposition to other nations, and instead opt for arrangements with public sectors in other countries. With the costs of escaping national jurisdictions going 
down to the private sectors in various countries, the "civil war" in which public sectors are engaged with private sectors encourages sharing of information and indeed may be a primary motivation behind regional arrangements such as the European Union and Nafta. Public sectors in different countries may share more interests in common than do public and private sectors within countries.

It is possible to point to some developments that seem to suggest a smaller role for the public sector. Thus de-nationalization of airlines, rail services, mining activities, and perhaps in some countries the postal services all seem to indicate a down-sizing of the public sector. But perhaps these changes merely reflect a focus by the public sector on those activities in which it has a core competence, viz. monitoring, regulating and controlling the activities undertaken by the private sector. But private sector firms now find it easier to shop around in other national jurisdictions that boast of different regulatory frameworks. As indicated above, the response of the public sector may entail abandoning some elements of sovereignty in order to line up taxation rates and the nature of regulation - in other words to harmonize (or collude). If there is one thing that national governments do not like and are not used to, it is competition. Witness the current pressure in the European Union for Ireland to raise its tax rates to levels found elsewhere, and thus to eradicate tax differentials as an inducement for private sector activities to move to Ireland instead of other locales in the EU. The stimulus for currently fashionable regional arrangements may come less from the private sector than it does from governments that are concerned that national boundaries are no longer sufficient in limiting the activities of its own citizens. 


\section{Concluding Remarks}

The analysis of national government policies is receiving increasing amounts of attention both from political scientists and from economists. The facet of the analysis that is the focus of this paper involves the consequences for government policy of the changes that have been taking place in world markets. In particular there have been drastic changes in the costs of coordinating activities over time and space. Transportation costs have been reduced and, more importantly, the costs of international communication have almost disappeared. This has led to an increased degree of fragmentation of production processes and mobility of capital and labor.

The ability of national governments to regulate and control the activities of its own citizens has been compromised by these changes. This has served as an inducement for the public sector to seek arrangements and alliances with other governments in order to extend the umbrella of its control. And the power of a national government to protect the interests of groups that do not possess the ability to move abroad is threatened by the ability of other elements of the private sector to pick and choose their preferred locale of residence and economic activity. In a previous age national governments were often called upon to provide national security in the event of war and foreign aggression and to keep foreign commercial interests from entering the national domain. Today it is often personal security that national governments claim as their rationale and they attempt to keep their own agents from escaping the domain of their control, even if it means joining with other governments, with the attendant diminution of sovereignty. 


\section{Footnotes:}

* e-mail: jonr@troi.cc.rochester.edu Fax: (716) 256-2309

1. As discussed in Kevin O'Rourke and Jeffrey Williamson (1999), international trade was somewhat comparable at the beginning of the $20^{\text {th }}$ century, with labor migration more prominent than in today's world.

2. See Ronald W. Jones and Henryk Kierzkowski (1990) and sources cited in Jones (2000), ch. 7.

3. This argument is based on Jones (1980) and Jones (2000), ch. 2.

4. If world markets are not perfectly competitive, even a small open economy can improve its terms of trade by a tariff, since it allows suppliers to engage in price discrimination. However, it may not be in the national interest to levy such a tariff. See Jones and Takemori (1989).

5. This proposition is proved in Jones (1984) and J. Peter Neary and Frances Ruane (1988).

6. See Jones (1985).

7. See William Niskanen (1971) and the contributions in Andre Blais and Stephane Dione (1991) for discussions of the motivations of bureaucrats. 


\section{References}

Blais, Andre and Stephane Dion (eds.), 1991. The Budget-Maximizing Bureaucrat, University of Pittsburgh Press.

Brander, James and Barbara Spencer, 1985. Export subsidies and market share rivalry. Journal of International Economics 18, 83-100.

Corden, W. Max, 1966. The structure of a tariff system and the effective protection rate. Journal of Political Economy 74, 221-37.

Dixit, Avinash and Gene Grossman, 1986. Targeted export promotion and several oligopolistic industries. Journal of International Economics, 21, 233-50.

Eaton, Jonathan and Gene Grossman, 1986. Optimal trade and industrial policy under oligopoly. Quarterly Journal of Economics, 101, 383-406.

Feeney, JoAnne and Arye Hillman, 2000. Privatization and the political economy of strategic trade policy. International Economic Review, forthcoming.

Hillman, Arye, 1989. The Political Economy of Protection, Harwood Publishers.

Jones, Ronald W., 1980. Comparative and absolute advantage. The Swiss Journal of Economics and Statistics, 3, 235-60.

-1984. Protection and the harmful effects of endogenous capital

flows. Economics Letters, 15, 325-30.

1985. Relative prices and real factor rewards: a

re-interpretation. Economics Letters, 26 (3), 47-49.

2000. Globalization and the Theory of Input Trade, MIT Press,

forthcoming.

Jones, Ronald W. and Henryk Kierzkowski, 1990. The role of services in production 
and international trade: a theoretical framework. In Jones and Anne Krueger (eds.), The Political Economy of International Trade. Blackwell's.

Jones, Ronald W. and Shumpei Takemori, 1989. Foreign monopoly and optimal tariffs for the small open economy. European Economic Review, 33, 1691-1707.

Neary, J. Peter and Frances Ruane, 1988. International capital mobility, shadow prices, and the cost of protection. International Economic Review, 29, 571-85.

Niskanen, William A.,, 1971. Bureaucracy \& Representative Government. Aldine. Atherton, Chicago.

O'Rourke, Kevin H. and Jeffrey G. Williamson, 1999. Globalization and History. MIT Press.

Rodrik, Dani, 1995. The political economy of trade policy. Ch. 28 in Grossman and Rogoff (eds.), Handbook of International Economics,. 3, 1457-94. North-Holland.

Spencer, Barbara and Ronald W. Jones, 1991. Vertical foreclosure and international. trade policy. The Review of Economic Studies, 58, 153-70.

Tyson, Laura D.,1992. Who's Bashing Whom? Trade Conflict in High Technology Industries, Institute for International Economics, Washington, D.C. 
